\title{
Relations Between Mothers' and Preschoolers' Use of Mental State Terms During Pretend Play and Preschoolers' Mental State Terms in Hypothetical Narratives
}

\author{
Nana Shin, Soyoung Kim \\ Department of Child Development, Ewha Womans University, Seoul, Korea \\ 가상놀이에서 어머니와 유아가 사용하는 마음상태 용어와 가상적 \\ 내러티브에서 유아가 사용하는 마음상태 용어 간 관계 \\ 신나나, 김소영 \\ 이화여자대학교 아동학과
}

Objective: This research examined mothers' and preschoolers' uses of mental state terms during pretend play and linked such use to children's independent mental state terms used in hypothetical narratives.

Methods: Fifty four-year-olds and their mothers were engaged in pretend play and the preschoolers were asked to provide hypothetical narratives. Mothers' and preschoolers' mental state terms were analyzed in terms of types and frequencies.

Results: During pretend play, the mothers and preschoolers used desire state terms most variously and frequently, followed by cognitive and emotion state terms. In the hypothetical narratives, the preschoolers used desire state terms most variously and frequently; however they talked about emotion state terms more variously and cognitive state terms more frequently. In addition, the mothers' mental state terms were correlated with the preschoolers' mental state terms during the pretend play, and the mothers' and preschoolers' uses of mental state terms during pretend play were related to the preschoolers' mental state terms in hypothetical narratives.

Conclusion: Findings from this study highlight that, during the preschool period, a mothers' mental state language might foster her child's understanding of mental states in himself/herself and in others.

Keywords: mental state term, pretend play, hypothetical narrative$$
\text { 서론 }
$$

우리가 매일의 일상에서 타인과 가지는 상호작용의 많은 부분 은 바램, 사고, 의도, 목표, 정서 등과 같은 내적인 심리적 상태

Corresponding Author: Nana Shin, Department of Child Development, Ewha Womans University, 52 Ewhayeodae-gil, Seodaemun-gu, Seoul 03760, Korea

E-mail: nanashin@ewha.ac.kr
\end{abstract}

에 관한 내용으로 구성되며, 이를 통해 타인과 효율적으로 의 사소통하며 사회적 관계를 형성, 유지해 나가게 된다. 자신과 타인의 심리적 상태를 이해하고 언어적으로 표현하는 능력은 마음상태 용어(mental state term)로 명명되어 1990년대 이래

(CThe Korean Association of Child Studies

This is an Open Access article distributed under the terms of the Creative Commons Attribution Non-Commercial License (http:// creativecommons.org/licenses/by-nc/4.0) which permits unrestricted noncommercial use, distribution, and reproduction in any medium, provided the original work is properly cited. 
연구되기 시작하였으며, 특히 마음상태 용어의 사용이 급격하 게 증가하는 걸음마기와 유아기에 초점을 두어 연구가 진행되 어 왔다. 유아기에 획득한 마음상태 용어는 이후 가정에서뿐 아니라 또래와의 일상 대화나 놀이에서 빈번하게 사용되며, 타인의 행동을 마음상태에 근거해서 예측하는 마음이론과도 중요한 관련성을 가지고 있는 것으로 보고되고 있어(Ruffman, Slade, \& Crowe, 2002; J. Song \& Ohm, 2008; Symons, Fossum, $\&$ Collins, 2006), 그 중요성이 강조되고 있다. 따라서 유아가 사용하는 마음상태 용어를 살펴봄으로써 유아의 마음에 대 한 이해를 살펴보고자 하는 연구가 활발하게 이루어지고 있다 (Symons, 2004).

마음상태 용어는 내적상태 용어(Bretherton \& Beeghly, 1982), 정신상태 동사(Shatz, Wellman, \& Silber, 1983), 정신상 태 용어(J. Song \& Ohm, 2008) 등으로 명명되어 연구되어 왔 다. 마음상태 용어의 하위범주는 연구자에 따라 다소 다르게 분류되고 있지만, 공통적으로 자신과 타인의 바람이나 소망을 나타내는 욕구상태 용어, 감정이나 느낌을 표현하는 정서상태 용어, 사고, 믿음, 지식을 나타내는 인지상태 용어를 포함한다 (Jenkins, Turrell, Kogushi, Lollis, \& Ross, 2003; J. Song \& Ohm, 2008). 이 중 인지상태 용어는 마음상태에 대한 유아의 표상을 반영하는 것으로, 가장 상위적인 마음상태 용어라 할 수 있다 (Bartsch \& Wellman, 1995).

마음상태 용어는 비교적 이른 시기에 출현하지만 그 하위 범주에 따라 발달 속도에는 다소 차이가 있다. 세 범주 중 가장 먼저 나타나는 것은 욕구상태 용어로, 걸음마기 시기에 나타 나 3세 이전까지 가장 빈번하게 사용된다(Bartsch \& Wellman, 1995; Moore, Furrow, Chiasson, \& Patriquin, 1994). 정서상태 용 어는 욕구상태 용어와 비슷한 시기에 나타나기 시작하며, 만 2세에서 3세 사이에 현저하게 증가한다(Bretherton \& Beehly, 1982; Dunn, Bretherton, \& Munn, 1987). 마지막으로, 인지상 태 용어는 이보다 늦은 시기인 3세 중반에 나타나기 시작하 여(Hughes \& Dunn, 1998; Shatz et al., 1983), 5세 경까지 계속 해서 사용빈도가 증가하는 것으로 보고되고 있다(Bartsch \& Wellman, 1995; Hughes \& Dunn, 1998; Wellman \& Woolley, 1990). 이러한 선행연구들을 통해 만 4세 시기에 유아는 욕구 상태나 정서상태 용어보다는 인지상태 용어를 더 많이 사용 할 것으로 가정해 볼 수 있지만, 몇몇 선행연구들은 이에 반하 는 결과 또한 보고하고 있다. 즉, Hughes, Lecce와 Wilson (2007) 의 연구에서는 만 4세 유아가 인지상태 용어보다는 욕구나 정 서상태 용어를 더 많이 사용하는 것으로 보고하였으며, 국내 에서 실시된 연구(J. Song \& Ohm, 2008)에서도 만 4세 유아가
인지나 정서상태 용어보다 욕구상태 용어를 더 많이 사용하는 것으로 보고되었다. 이렇듯 선행연구들은 연령에 따라 마음상 태 용어의 하위범주 중 어느 것이 더 빈번하게 사용되는지에 대해서는 다소 다른 결과를 보고하고 있지만, 만 4세 경이 되 면 유아는 세 가지 범주의 마음상태 용어를 습득하게 되고, 이 를 일상 대화에서 보다 능숙하고 빈번하게 사용하는 것으로 일관적으로 보고하고 있다(Jenkins \& Astington, 2000).

한편, 마음상태 용어를 살펴본 대부분의 연구들(Bartsch \& Wellman, 1995; Brown, Donelan-McCall, \& Dunn, 1996; Brown \& Dunn, 1991; Hughes \& Dunn, 1997; Jenkins et al., 2003; Lee \& Lee, 2006; Nielsen \& Dissanayake, 2000; Osório, Meins, Martins, Martins, \& Soares, 2012; Rudek \& Haden, 2005; J. Song $\& \mathrm{Ohm}, 2008)$ 에서는 마음상태 용어가 사용되는 빈도, 즉 마 음상태 용어가 얼마나 빈번하게 사용되는지에 초점을 두는 경 향이 있었다. 하지만 최근에는 마음상태 용어의 사용을 보다 정확하게 반영하기 위해서는 빈도 뿐 아니라 마음상태 용어의 유형, 즉 얼마나 다양한 마음상태 용어를 사용하는지를 함께 측정해야 한다는 주장들이 나타나고 있다(Adrian, Clemente, Villanueva, \& Rieffe, 2005; Dyer, Shatz, \& Wellman, 2000; Howe, Rinaldi, \& Recchia, 2010; Ji \& Jo, 2010). 따라서 본 연구에서는 어머니와 유아의 마음상태 용어의 사용을 측정하는 데 있어, 사용 유형과 사용 빈도를 모두 포함하여 측정하였다.

유아기 마음상태 용어의 획득에 영향을 미치는 요인을 살펴본 선행연구들은 유아가 타인과 가지는 언어적 상호작 용의 중요성을 강조한다(Bartsch \& Wellman, 1995; Nelson, 2005; Symons, 2004; Thompson, 2006). 이는 Vygotsky (1978) 의 발판화(scaffolding)와 Rogoff (1990)의 인도된 참여(guided participation)의 개념으로도 설명될 수 있는데, 두 이론에서는 모두 개인의 어휘 획득과 내러티브 기술이 초기 부모와의 상 호작용을 통해 학습되고 내면화되는 발달적 과정을 설명하 고 있다. 즉, 부모-자녀간 언어적 상호작용 초기에는 어머니가 대부분의 상호작용을 이끌어나가지만, 언어발달이 급격하게 이루어지는 유아기 동안 유아는 보다 능동적으로 대화에 참 여하기 시작한다. 이러한 과정을 통해 유아는 부모의 대화 내 용이나 유형을 내면화하여 개인의 안정적인 대화 특성을 만 들어 나가게 되고, 이를 타인과의 상호작용 시 사용하게 된다 (Carlson, Mandell, \& Williams, 2004; Hughes \& Dunn, 1998). 특히 유아와 가장 많은 시간을 함께 보내는 어머니는 아버지 보다 언어적 상호작용에 더 많은 시간을 투자하고, 좀 더 지 지적인 대화를 나눌 뿐 아니라(Leaper, Anderson, \& Sanders, 1998), 자녀가 경험하는 정서에 대해 더 많은 대화를 나눈다 
(Kuebli, Butler, \& Fivush, 1995). 또한 Jenkins 등(2003)은 가정 에서 어머니 및 아버지가 유아와 상호작용하는 것을 관찰한 결과, 유아는 어머니와 상호작용 시 마음상태에 대해 더 많이 이야기를 하고, 더 분화된 마음상태 용어를 사용하며, 어머니 는 유아의 발달적인 욕구에 민감하며 유아에게 더 높은 수준 의 자극을 제공하는 것으로 보고하였다. 즉, 유아는 어머니와 의 상호작용을 통해 타인의 마음상태에 대한 이해를 확장해 나가고, 자신과 타인의 마음상태를 언어를 통해 표현하고 구 체화하는 방법을 학습하게 되며, 이를 내면화하게 된다는 것 이다. 따라서 본 연구에서는 어머니와 유아 간 언어적 상호작 용에 초점을 두어 마음상태 용어 간 관련성을 살펴보았다.

어머니와 유아의 마음상태 용어 사용은 다양한 상황에 서 연구되었는데, 책읽기(Ji \& Jo, 2010; H. Kim, 2014; Ziv, Smadja, \& Aram, 2013), 가상놀이(H. Kim, 2014; Osório et al., 2012; Symons et al., 2006), 과거회상 대화(Ontai \& Thompson, 2008; Rudek \& Haden, 2005), 자유 놀이(Jenkins et al., 2003) 등 이 이에 포함된다. 이 중 가상놀이는 시공간, 역할 혹은 사물 을 실제와 다르게 변형하여 놀이하는 것을 의미하는 것으로 (Y. Kim \& Lee, 2003), 생후 15개월 경 혼자놀이의 형태로 나타 나기 시작하여, 만 4세 경이 되면 다른 사람과 함께 하는 형태 의 사회적 가상놀이 혹은 공동 가상놀이(joint pretense)에 활발 하게 참여하게 된다. 가상놀이에서 어머니와 유아는 가상적인 상황이나 공간에서 서로가 담당하는 역할과 현실에서 담당하 는 역할을 수시로 넘나들면서 자연스럽게 이야기 속의 인물과 서로의 마음상태를 나타내는 마음상태 용어를 사용하게 되기 때문에(Hughes \& Dunn, 1997, 1998), 가상놀이는 유아의 마음 상태 용어의 사용을 촉진하는 환경으로 널리 연구되어 왔다.

가상놀이 상황에서 어머니와 유아가 사용하는 마음상태 용 어를 살펴본 연구들에서는 어머니와 유아가 사용하는 마음상 태 용어 간 관련성을 일관적으로 보고하고 있다(Osório et al., 2012; Symons et al., 2006). 이를 보다 구체적으로 살펴보면, 가 상놀이에서 어머니가 욕구상태 용어를 더 많이 사용할수록 유 아도 욕구상태 용어를 더 많이 사용하였다(Osório et al., 2012). 또한 Symons 등(2006)은 어머니의 적절한 욕구상태 용어와 인 지상태 용어의 사용은 유아의 욕구상태 용어와 인지상태 용어 와 관련이 있었으며, 범주 간 교차 상관은 유의하지 않은 것으 로 보고하였다. 이외 과거회상 대화나 책읽기 상황의 경우 어 머니와 유아가 사용하는 마음상태 용어의 사용 유형이나 빈 도에서는 개인차가 나타났지만(Howe et al., 2010; Rosnay \& Hughes, 2006), 어머니와 유아가 사용하는 마음상태 용어의 사 용 유형과 빈도 간 관련성은 횡단연구(Rudek \& Haden, 2005;
Ruffman et al., 2002)와 종단연구(Taumoepeau \& Ruffman, $2006,2008)$ 에서 일관적으로 보고되었다. 즉, 가상놀이뿐 아니 라 과거회상 대화나 책읽기 상황 등 다양한 상황에서 어머니 의 마음상태 용어와 유아의 마음상태 용어 간 관련성이 확인 되었다.

이렇듯 국외에서 진행된 연구들에서는 어머니와 유아가 상 호작용 시 사용하는 마음상태 용어 간의 관련성을 보고하고 있지만, 국내의 경우에는 유아만을 대상으로 마음상태 용어 를 살펴본 연구들(Lee \& Lee, 2006; Lee, Lee, \& Shin, 2004; Lee \& Oh, 2007; K. Park \& Kwon, 2011; J. Song \& Ohm, 2008; Y. Song, 2009)이 대부분이며, 어머니와 유아를 동시에 포함한 연 구는 드물게 이루어졌다(Ji \& Jo, 2010; H. Kim, 2014). 이러한 연구들 중 H. Kim (2014)은 가상놀이 시 어머니가 사용하는 마음상태 용어의 사용에만 초점을 두었지만, Ji와 Jo (2010)는 36 70개월의 유아와 어머니가 그림책을 읽으며 상호작용하 는 동안 어머니와 유아가 사용한 마음상태 용어의 유형과 빈 도 간 관련성을 살펴보았다. 그 결과, 마음상태 용어 간 관련성 을 발견하였으며, 구체적으로 정서상태 용어의 유형과 인지상 태 용어의 유형 및 빈도에서 어머니와 유아 간 관련성을 보이 는 것으로 보고하였다.

한편, 앞서 언급한 것처럼 Vygotsky (1978)와 Rogoff (1990) 는 유아가 어머니와의 상호작용을 통해서 마음상태 용어를 학 습하고, 이를 다른 상황에서 독립적으로 사용하는 과정에 대 한 이론적 근거를 제시하고 있다. 하지만 마음상태 용어를 살 펴본 선행 연구들은 어머니와 유아의 마음상태 용어 간 유사 성만을 살펴보았을 뿐, 유아가 어머니 이외의 타인과 상호작 용 시 독립적이고 자발적으로 제공하는 마음상태 용어에 대해 서는 탐색하지 않았다는 제한점이 있다. 다만 Taumoepeau과 Ruffman (2008)의 연구에서 24개월 때 어머니가 사용한 마음 상태 용어가 자녀가 33개월이 되었을 때 일반적으로 사용하 는 마음상태 용어를 예측하는 것으로 보고하였으며, 이외 몇 몇 연구에서 유아가 친구(Comparini, Douglas, \& Perez, 2014; Hughes \& Dunn, 1998)나 형제자매(Hughes, Marks, \& Ensor, 2009)와의 상호작용에서 사용하는 마음상태 용어를 살펴보는 데 그치고 있다. 또한 어머니가 가상놀이나 그림책 읽기 등 다 양한 상호작용 상황에서 사용하는 마음상태 용어를 살펴본 연 구들(Howe et al., 2010; H. Kim, 2014)은 나타나고 있지만, 유 아가 어머니와의 상호작용 이외의 상황에서 독립적으로 사용 하는 마음상태 용어를 살펴본 연구는 Brown 등(1996)의 연구 를 제외하고는 찾아보기 힘들다.

유아가 독립적으로 산출하는 마음상태 용어의 사용을 살펴 
보기 위한 상황으로 최근 가상적 내러티브에 대한 관심이 커 지고 있다. 내러티브는 자신의 생각이나 감정을 표현하는 의 사소통의 한 양식으로, 가상적 내러티브는 특정 주제를 가지 고 있는 가상적 상황에서 이야기를 만들어 내는 것을 의미한 다(Haight \& Miller, 1993). 가상적 내러티브에서 유아는 자신 의 생각이나 감정을 이야기에 등장하는 주인공에게 투사하여 나타내기 때문에, 가상적 내러티브는 유아의 내적 사고나 정 서를 살펴보기 위한 신뢰롭고 타당한 방법으로 알려져 왔다 (Bettmann \& Lundahl, 2007; Robinson, 2007). 실제 가상적 내 러티브에서 유아가 사용하는 마음상태 용어를 살펴본 선행연 구들에서는, 유아가 인지상태 용어보다 정서상태 용어를 더 많이 사용하며(Lee \& Lee, 2006), 그림책 읽기나 이야기 나누 기 활동 등이 유아의 마음상태 용어 사용을 촉진한다고 보고 하였다(Lee \& Oh, 2007). 이러한 연구들에 근거하여, 본 연구 에서는 어머니와 유아가 함께 참여하는 가상놀이와 유아가 실 험실 상황에서 독립적으로 작성하는 가상적 내러티브에서 사 용한 마음상태 용어 간 관련성을 살펴봄으로써, 이 시기 마음 상태 용어의 사용이 유아의 개인적인 특성으로 내면화되고 있 는지 살펴보고자 하였다.

지금까지 살펴본 것처럼 유아는 어머니와의 상호작용을 통 해 마음상태 용어를 습득하고 발달시켜 나간다. 이에 관한 선 행연구들이 국외에서는 활발하게 진행되었지만, 국내의 경우 에는 어머니와 유아 간 마음상태 용어의 관련성을 살펴보는 연구가 드물게 나타나고 있으며, 특히 가상놀이 상황에서 어 머니와 유아가 사용하는 마음상태 용어 간 관련성을 살펴본 연구는 나타나고 있지 않다. 또한 마음상태 용어를 살펴본 대 부분의 연구에서 마음상태 용어가 내면화되는 과정에 관해서 는 언급하고 있지만, 실제로 어머니와 유아 간 상호작용 시 어 머니와 유아가 사용하는 마음상태 용어가 유아가 독립적으로 산출하는 가상적 내러티브에서 사용하는 마음상태 용어와 어 떠한 관련을 가지는지에 대한 연구는 찾아보기 힘들다. 이 시 기 마음상태 용어의 발달이 또래집단에서 유아의 성공적인 적 응을 돕는 타인의 정서나 마음상태를 이해하는 데 중요한 역 할을 담당한다는 점(Ruffman et al., 2002; Symons et al., 2006) 을 고려해 볼 때, 유아기 마음상태 용어가 발달되고 내면화 되 는 과정에 대해 주목할 필요가 있다. 따라서 본 연구에서는 가 상놀이 상황에서 어머니와 유아가 사용하는 마음상태 용어 의 사용양상 및 관련성을 살펴보고, 가상놀이 시 어머니와 유 아가 사용하는 마음상태 용어가 가상적 내러티브에서 유아가 사용하는 마음상태 용어와 관련이 있는지 살펴봄으로써 유아 기 마음상태 용어의 사용에 관한 기존 연구를 확장하고자 하
였다. 또한 유아의 언어능력과 마음상태 용어 간 관련성을 보 고한 선행연구들(Bartsch \& Wellman, 1995; Cutting \& Dunn, 1999; Lee \& Lee, 2006; Ji \& Jo, 2010)에 근거하여, 어머니와 유 아의 마음상태 용어 사용양상 및 관계를 살펴보는 데 있어 유 아의 언어적 능력의 영향을 고려하였다. 본 연구의 구체적인 연구문제는 다음과 같다.

\section{연구문제 1}

가상놀이와 가상적 내러티브에서 어머니와 유아가 사용하는 마음상태 용어의 일반적 경향은 어떠한가?

\section{연구문제 2}

가상놀이에서 어머니와 유아가 사용하는 마음상태 용어 간 관계는 어떠한가?

\section{연구문제 3}

가상놀이에서 어머니와 유아가 사용하는 마음상태 용어와 가 상적 내러티브에서 유아가 사용하는 마음상태 용어 간 관계 는 어떠한가?

\section{연구방법}

\section{연구대상}

본 연구의 대상은 서울시에 거주하는 만 4 세 유아와 그들의 어 머니 50쌍이다. 본 연구의 대상을 만 4 세 유아로 선정한 이유 는 이 시기에 타인의 마음상태를 정신적으로 표상할 수 있으 며(Flavell, 2000; Wellman, Cross, \& Watson, 2001), 마음상태 용 어의 하위 범주의 출현 시기와 발달 속도는 차이를 보이지만 (Bartsch \& Wellman, 1995; Bretherton \& Beehly, 1982), 만 4세 경이 되면 유아는 세 가지 범주의 마음상태 용어를 타인과의 대화에서 자유롭게 사용할 수 있기 때문이다.

연구대상의 사회인구학적 특성을 살펴보면 남아가 23 명 (46\%), 여아가 27명(54\%)으로 여아가 다소 많았으며, 대부분 의 유아(48명, $96 \%)$ 가 유치원이나 어린이집에 재원 중이었 다. 평균 월령은 53.98 개월 $(S D=3.85)$ 이었으며, 이를 세분화 해보면 48 50개월이 13명(26\%), 51 53개월이 13명 $(26 \%)$, 54 56개월이 7명(14\%), 57 60개월이 13명(26\%)이었다. 출 생순위의 경우, 전체 유아 중 외동이가 22 명(44\%)이었으며, 외동이가 아닌 경우에는 첫째가 22명(44\%), 둘째가 6명(12\%) 
으로 외동이의 비율이 가장 높았다. 어머니의 평균 연령은 36.55 세 $(S D=3.10)$ 로, 30 대가 41 명 $(826 \%)$ 으로 가장 많았고, 그 다음으로 40 대 이상이 8 명(16\%)이었고 20대가 1 명(2\%)이 었다. 어머니의 교육 수준의 경우 대학교 졸업이 29 명 $(58 \%)$ 으로 가장 많았고, 전문대 졸업 및 대학교 중퇴가 11명(22\%) 으로 그 뒤를 이었다. 26명(52\%)의 어머니가 전업주부였으 며, 24 명 $(48 \%)$ 의 어머니가 직업을 가지고 있었다. 가정의 월 평균소득은 500만원 이상인 가정이 21가구(42\%)로 가장 많 았으며, 400 500만원인 가정이 13 가구(26\%), 300 400만원 인 가정이 10 가구(20\%), 200 300만원인 가정이 5가구(10\%), $100-200$ 만원인 가정이 1 가구(2\%) 순으로 나타났다. 따라서 연구대상 유아의 가정은 대부분 중산층 이상에 속하는 것으로 볼 수 있다.

\section{연구도구}

본 연구에서는 실험실 상황을 이용하여 가상놀이에서 어머니 와 유아의 마음상태 용어, 그리고 가상적 내러티브에서 유아 의 마음상태 용어를 측정하였다. 유아의 언어능력은 언어성 지능 검사를 사용하여 측정하였다. 각 연구도구에 대해 구체 적으로 살펴보면 다음과 같다.

\section{어머니와 유아의 마음상태 용어}

어머니와 유아가 사용한 마음상태 용어는 Bartsch와 Wellman (1995), Ruffman 등(2002), J. Song과 Ohm (2008)을 참조하여 코딩하였다. 마음상태 용어는 욕구상태 용어, 정서상태 용어, 인지상태 용어의 세 가지 범주로 구분하여 분석하였으며, 개 인의 욕구, 정서, 인지상태를 직접적으로 나타내는 용어들(예: ‘원하다', ‘화가 나다', '생각하다')뿐 아니라 ‘ 하고 싶다', ‘인 것 같다' 등과 같은 양태표현도 분석에 포함하였다. 각 범주를 보다 구체적으로 살펴보면 욕구상태 용어는 개인의 바람, 소 망, 요구 등을 나타내는 용어를 의미하는 것으로, '원하다', '바 라다', '필요하다' 등과 같은 용어와 ' 하고 싶다', ' 했으면 좋 겠다' 등과 같은 용어들이 포함된다. 정서상태 용어는 내면적 감정이나 느낌 등을 표현하는 용어로 '기쁘다', '화나다'와 같 이 다양한 내적인 정서상태를 나타내는 표현들로 구성되어 있 다. 그리고 인지상태 용어는 자신과 타인의 지식, 사고, 기억, 신념 등을 표현하는 용어로 '생각하다'와 '알다'와 같은 용어와 ' 인것 같다', ' 일지도 모른다'와 같은 용어들로 구성된다.

마음상태 용어는 발화단위로 구분하여 분석하였는데, 각
발화단위에 마음상태 용어가 나타날 경우 문맥을 고려하여 세 가지 범주 중 어느 범주에 해당하는지 판단하였다. 전체 발 화를 대상으로 마음상태 용어를 세 가지 하위범주로 분류를 마친 후, 다음 단계에서는 각 범주 별 사용 유형과 빈도를 측 정하여 각각 점수화하였다(Adrian et al., 2005; Ji \& Jo, 2010). 사용 유형은 어머니와 유아가 각 범주에 해당하는 용어를 얼 마나 다양하게 사용하였는지를, 사용 빈도는 각 범주에 해당 하는 마음상태 용어를 얼마나 많이 사용하였는지를 의미한 다. 예를 들어 유아가 가상놀이에서 정서상태 용어에 해당되 는 '기뻤어, 슬펐어, 기뻤는데, 놀랐어, 놀랐는데'와 같은 용어 를 사용했다면, 정서상태 용어의 사용 유형 점수는 기쁨, 슬 픔, 놀람의 세 가지를 포함하므로 3점이 되며, 사용 빈도 점수 는 5점이 된다.

마음상태 용어의 사용 유형과 빈도를 점수화하는데 다음과 같은 몇 가지 규칙을 사용하였다. 첫째, 하나의 발화에서 같은 범주에 속하는 마음상태 용어가 여러 번 반복되더라도 1점으 로 계산하였으며, 한 문장 안에 여러 가지 다른 범주의 마음상 태 용어가 나타나는 경우에는 각각 1점씩 부여하였다. 예를 들 어, '엄마는 슬프다고 생각해’의 경우 ‘슬프다'는 정서상태 용 어 범주이고 '생각해'는 인지상태 용어 범주이기 때문에 각 범 주에 각각 1 점의 점수를 부여하였다. 둘째, 각각의 마음상태 용어는 하나의 범주에만 속하도록 상호배타적으로 코딩하였 다. 셋째, 마음상태 용어의 시제나 품사가 달라지더라도 마음 상태를 표현하고 있다면 마음상태 용어로 코딩하였다. 예를 들어 '기억하다'라는 동사를 '기억했어'라고 시제를 바꾸어서 사용한 경우나 ‘내 기억은 그래'라고 명사로 바꾸어 사용한 경 우에도 점수를 부여하였다. 넷째, 관찰 가능한 행동(울다, 웃 다, 찡그리다)이나 신체적 상태(배고프다, 아프다, 지치다), 평 가(멋진데, 좋은데)등은 내적인 마음상태를 표현하는 것이 아 니기 때문에 마음상태 용어에 포함하지 않았다. 다섯째, 선행 연구들(Ji \& Jo, 2010; J. Song \& Ohm, 2008)에서 제시한 것처 럼 관용적 표현, 습관적인 표현, 모방하거나 반복하는 말, 단순 하게 상대방의 말에 반응하는 말, 감탄사, 노래 부르기, 숫자 세기, 무의미한 소리 등은 분석에서 제외하였다. 마지막으로 유아의 마음상태 용어 측정 시 어머니(가상놀이)나 연구자(가 상적 내러티브)가 사용한 마음상태 용어를 바로 반복한 경우, 즉 자발적으로 나타난 마음상태 용어가 아닌 경우에는 분석에 포함하지 않았다.

이러한 과정을 거쳐 본 연구에서는 어머니와 유아를 분리 하여 가상놀이와 가상적 내러티브에서 사용한 마음상태 용어 의 사용 유형과 사용 빈도 총합을 계산하였다. 선행연구에서 
는 마음 상태 용어를 전체 발화 수 대비 마음상태 용어가 나타 난 비율을 계산(Osório et al., 2012; Symons, Peterson, Slaughter, Roche, \& Doyle, 2005)하거나 총합(Lee \& Lee, 2006; Rudek \& Haden, 2005; J. Song \& Ohm, 2008)을 계산하였다. 본 연구 에서는 마음상태 용어가 전체 발화 중 어느 정도를 차지하는 지 보다는 사용된 마음상태 용어 각각이 아동이 마음상태를 이해하는 데 직접적인 영향을 미친다는 Ruffman 등(2002)과 Symons 등(2006)의 제안에 근거하여, 마음상태 총합을 계산하 여 분석에 사용하였다.

마음상태 용어의 분석에는 본 연구의 주저자와 세 명의 보 조 연구자가 참여하였다. 보조 연구자들은 사전에 마음상태 용어에 대한 훈련을 받았으며, 훈련을 마친 후 전체의 $10 \%$ 인 5 쌍의 어머니와 유아의 전사본에 대해 각자 코딩한 후 불일치 한 결과가 있을 경우 토론을 통하여 이를 조정하였다. 전사본 에서 문맥에 따른 의미가 명확하지 않을 경우에는 녹화된 비 디오를 확인하였다. 그 후 45 쌍의 어머니와 유아의 전사본 중 15 쌍의 전사본(33.3\%)을 본 연구의 주저자가 모두 코딩하고, 세 명의 보조 연구자가 각각 5 쌍의 전사본을 평가한 후 주저자 와 보조 연구자 간 신뢰도를 산출하였다. 그 결과, 각 하위범주 별 평가자 간 신뢰도는 욕구상태 용어 유형 .75 .90, 욕구상태 용어 빈도 .82 .97, 정서상태 용어 유형 .91 .98, 정서상태 용 어 빈도 .89 .97, 인지상태 용어 유형 .72 .88, 인지상태 용어 빈도 .71 .84이었다. 평가자 간 신뢰도를 확립하는 데 사용된 전사본의 경우, 신뢰도 산출 후 주저자와 보조연구자들이 함 께 불일치한 부분을 점검하여 확인한 후, 최종 점수를 산출하 였다. 이후 30 쌍의 전사본은 참여한 연구자가 분담하여 코딩 하였다.

\section{유아의 언어성 지능}

유아의 언어성 지능은 H. Park, Kwak과 Park (1996)의 한국 웩 슬러 유아 지능검사(Korean-Wechsler Preschool and Primary Scale of Intelligence [K-WPPSI]) 중 언어성 지능과 관련된 소검사를 사용하여 측정하였다. 언어성 지능 소검사는 상식(27문항), 이 해(15문항), 산수(23문항), 어휘(25문항), 공통성(20문항), 문장 (12문항)으로 구성되어 있는데, 본 연구에서는 보충검사인 문 장을 제외하고 다섯 가지 영역의 소검사를 사용하였다. 각 소 검사마다 유아가 획득한 점수를 연령에 따른 표준화 점수 기 준에 따라 환산점수로 변환한 후, 다섯 개 영역에서 획득한 점 수를 합산하여 유아의 최종 언어성 지능 점수를 계산하였다. 점수가 높을수록 유아의 언어능력이 높은 것을 의미한다.

\section{연구절차}

예비조사

가상놀이, 가상적 내러티브, 그리고 언어성 지능 검사의 절차 및 총 실험 시간이 만 4세 유아에게 적절한지 살펴보기 위하 여, 연구대상과 같은 연령인 만 4 세 유아와 어머니 3 쌍을 대상 으로 예비조사를 실시하였다. 그 결과, 참여한 유아들은 가상 놀이와 가상적 내러티브 작성, 언어성 지능 검사를 수행하는 데 어려움을 보이지 않았으며, 과제를 수행하는 실험실 장소 및 실험 순서, 전체 소요 시간, 유아의 과제에 대한 집중도 등 에서도 문제가 없음을 확인하였다.

\section{본조사}

본 연구의 대상은 어린이집에 공문을 보내거나 인터넷 육아카 페에 안내문을 공고하여 모집하였다. 어린이집과 육아카페에 공고된 안내문을 보고 참여의사를 보인 어머니들에게, 연구 자가 직접 전화로 일정을 조율하였으며, 최종 31 명의 어머니 가 육아카페를 통해, 19 명의 어머니가 어린이집에 공고한 안 내문을 보고 연구에 참여하였다. 실험실 방문 시 연구자는 함 께 대기실로 이동하여 어머니에게 연구 절차와 방법 등에 대 해 설명을 하고 연구동의서를 받았다. 그 후 어머니와 유아는 실험실로 이동하여 가상놀이에 먼저 참여하였다. 가상놀이를 진행하기 위하여 선행연구들(Hughes \& Dunn, 1997; Osório et al., 2012; Tamis-LeMonda \& Bornstein, 1990)을 참고하여 유아 에게 친숙하고, 유아가 쉽게 다룰 수 있으며, 다양한 가상놀이 를 가능하도록 하는 놀잇감을 제공하였다. 이러한 놀잇감에는 가족인형, 동물 인형, 가구와 소품, 음식 소품, 자동차, 블록 등 이 포함되었으며 가상놀이를 시작하기 전 실험실 한 가운데에 배치하였다. 연구자는 어머니에게 놀이 시간은 20 여분으로, 가정에서 유아와 놀이할 때처럼 편안하고 자유로운 방식으로 놀이하도록 안내하였다.

가상놀이 완료 시 어머니는 대기실로 자리를 옮기고 유 아는 연구자와 실험실에 남아 가상적 내러티브 과제와 언 어성 지능검사를 수행하였다. 유아의 가상적 내러티브는 Bretherton, Oppenheim, Buchsbaum과 Emde (1990)가 고안 한 MacArthur 이야기 완성 과제(MacArthur Story Stem Battery [MSSB])를 통하여 측정하였다. MSSB는 인형집과 인형들, 다 양한 소품을 사용하여 가상적인 상황에서 유아의 내적 표상 을 살펴보기 위한 도구로, 본 연구에서는 워밍업 이야기인 생 
일파티 이야기와 7개의 가상적인 주제(예: 부모와의 분리와 재결합, 국 엎지르기, 소외)를 중심으로 유아가 이야기를 구성 하도록 하였다. MSSB는 생일파티 이야기로 시작되는데, 이 는 유아가 내러티브 작성에 사용되는 도구들, 즉 가족인형이 나 자동차, 가구 등의 소품을 사용하여 이야기를 만드는 것에 친숙해 지도록 하기 위함이다. 그 후 갈등적인 상황을 포함하 는 본 이야기에서는 연구자가 유아에게 이야기의 갈등상황을 제시한 후 유아가 자신만의 이야기를 완성하도록 한다. 연구 자는 유아가 이야기를 하지 않을 경우 이를 격려하기 위한 발 언(예: “무슨 일이 생길까?”)을 제외하고는 이야기를 주도하지 않으며, 유아의 이야기에 반응하거나 유아의 이야기를 따라가 도록 훈련되었다. 가상적 내러티브 작성에는 $20 \sim 25$ 분이 소 요되었으며, 이후 실시된 언어성 지능 검사에는 $10 \sim 15$ 분이 소요되었다. 모든 과정은 추후 분석을 위하여 비디오로 녹화 되어 전사되었다.

\section{자료분석}

본 연구에서 수집된 자료는 SPSS 23.0 (IBM Co., Armonk, NY) 프로그램을 사용하여 다음과 같은 방법으로 분석하였다. 첫 째, 어머니와 유아의 마음상태 용어의 일반적인 경향을 알아 보기 위하여 기술통계를 실시하였다. 둘째, 유아의 언어 능력 이 마음상태 용어 사용에 영향을 미치는지 살펴보기 위하여 상관관계 분석을 실시하였다. 셋째, 유아의 언어적 능력을 통 제한 후 가상놀이 시 어머니와 유아가 사용하는 마음상태 용 어 간 관련성을 살펴보기 위하여 편상관관계 분석을 실시하였 다. 마지막으로, 가상놀이에서 어머니와 유아의 마음상태 용 어와 가상적 내러티브에서 유아의 마음상태 용어 간 관련성을 유아의 언어 능력을 통제하고 살펴보기 위하여 편상관관계 분 석을 실시하였다.

\section{연구결과}

\section{마음상태 용어의 사용 유형 및 빈도}

어머니와 유아가 사용한 마음상태 용어의 일반적인 경향을 살 펴보기 위해 가상놀이와 가상적 내러티브를 통해 측정한 어머 니와 유아의 마음상태 용어의 사용 유형과 빈도에 대한 기술 통계를 실시하였다(Table 1). 먼저, 가상놀이에서 어머니가 사 용한 마음상태 용어의 유형을 살펴보면, 욕구상태 용어가 평
균적으로 4.84 가지 $(S D=2.04)$ 로 가장 다양하게 사용되었으 며, 그 다음으로 인지상태 용어 $(M=4.26, S D=1.99)$, 정서상 태 용어 $(M=3.38, S D=2.04)$ 순으로 사용되었다. 즉, 어머니 는 유아와의 가상놀이에서 욕구상태 용어를 가장 다양하게 사 용하였으며, 그 다음으로 인지상태 용어와 정서상태 용어 순 으로 다양하게 사용하였다. 다음으로 마음상태 용어의 사용 빈도를 살펴보면, 사용 유형과 마찬가지로 욕구상태 용어가 가장 빈번하게 사용되었으며 $(M=13.66, S D=9.52)$, 인지상태 용어가 9.62회 $(S D=6.34)$, 정서상태 용어가 6.82 회 $(S D=5.02)$ 순으로 사용되었다. 즉, 어머니가 유아와의 가상놀이에서 욕 구상태 용어를 가장 많이 사용하였으며, 그 다음으로 인지상 태 용어와 정서상태 용어를 사용했음을 알 수 있었다.

다음으로 가상놀이에서 유아가 사용한 마음상태 용어의 사용양상을 살펴보면, 먼저 사용 유형과 관련하여 유아는 평 균적으로 3.58 가지 $(S D=1.80)$ 의 욕구상태 용어를 사용하였 으며, 인지상태 용어는 2.36 가지 $(S D=1.86)$, 정서상태 용어는 1.60 가지 $(S D=1.31)$ 를 사용하였다. 즉, 유아 역시 어머니와 마 찬가지로 가상놀이에서 욕구상태 용어를 가장 다양하게 사용 하였고, 그 다음으로 인지상태 용어와 정서상태 용어를 다양 하게 사용하였다. 유아의 마음상태 용어 사용 빈도도 이와 유 사하여, 욕구상태용어 8.46회 $(S D=7.04)$, 인지상태용어 3.64 회 $(S D=3.42)$, 정서상태 용어 2.46 회 $(S D=2.01)$ 순서로 나타 나 유아 역시 어머니와 마찬가지로 가상놀이에서 욕구상태 용 어를 가장 많이 사용하였다.

마지막으로 가상적 내러티브에서 유아가 사용한 마음상 태 용어의 유형과 빈도를 살펴보면, 평균적으로 욕구상태 용 어가 2.44가지 $(S D=1.39)$ 로 가장 다양하게 사용되었고, 그 다 음으로 정서상태 용어가 2.30 가지 $(S D=1.61)$, 인지상태 용어 가 2.22가지 $(S D=1.59)$ 사용되었다. 다시 말해 가상적 내러티 브에서 유아는 가상놀이에서 보여준 것과 마찬가지로 욕구상 태 용어를 가장 다양하게 사용하였지만, 정서상태 용어와 인 지상태 용어의 사용 유형에는 다소 차이를 보였다. 반면 가상 적 내러티브에서 유아가 사용한 마음상태 용어의 빈도는 욕구 상태 용어가 5.04회 $(S D=4.94)$, 인지상태 용어가 4.02회 $(S D=$ $3.33)$, 정서상태 용어가 2.90회 $(S D=2.37)$ 의 순서로 나타나 가 상놀이에서 유아가 사용한 마음상태 용어의 사용 빈도와 유사 한 양상을 보였다.

\section{유아의 언어적 능력과 마음상태 용어 간 관계}

유아의 언어적 능력이 가상놀이에서 어머니와 유아가 사용한 
Table 1

Types and Frequencies of Mental State Terms Used by Mothers and Preschoolers

\begin{tabular}{|c|c|c|c|c|c|c|}
\hline Context & Subject & Usage & Category & $M$ & $S D$ & Range \\
\hline \multirow[t]{12}{*}{ Pretend play } & Mother & Type & Desire & 4.84 & 2.04 & 7 \\
\hline & & & Emotion & 3.38 & 2.04 & 9 \\
\hline & & & Cognition & 4.26 & 1.99 & 9 \\
\hline & & Frequency & Desire & 13.66 & 9.52 & 39 \\
\hline & & & Emotion & 6.82 & 5.02 & 20 \\
\hline & & & Cognition & 9.62 & 6.34 & 31 \\
\hline & Preschooler & Type & Desire & 3.58 & 1.80 & 6 \\
\hline & & & Emotion & 1.60 & 1.31 & 5 \\
\hline & & & Cognition & 2.36 & 1.86 & 8 \\
\hline & & Frequency & Desire & 8.46 & 7.04 & 33 \\
\hline & & & Emotion & 2.46 & 2.01 & 8 \\
\hline & & & Cognition & 3.64 & 3.42 & 15 \\
\hline \multirow[t]{6}{*}{ Hypothetical narrative } & Preschooler & Type & Desire & 2.44 & 1.39 & 6 \\
\hline & & & Emotion & 2.30 & 1.61 & 6 \\
\hline & & & Cognition & 2.22 & 1.59 & 6 \\
\hline & & Frequency & Desire & 5.04 & 4.94 & 24 \\
\hline & & & Emotion & 2.90 & 2.37 & 12 \\
\hline & & & Cognition & 4.02 & 3.33 & 14 \\
\hline
\end{tabular}

Note. $N=50$.

마음상태 용어와 가상적 내러티브에서 유아가 사용한 마음상 태 용어와 관련이 있는지 알아보기 위하여 Pearson의 적률상관 계수를 산출하였다. 그 결과, 유아의 언어적 능력은 가상놀이 에서 어머니의 마음상태 용어 사용 유형 $(r=.33, p<.05)$ 과 어 머니의 인지상태 용어 사용 유형 $(r=.35, p<.05)$, 가상적 내러 티브에서 유아의 욕구상태 용어 사용 유형 $(r=.35, p<.05)$ 과 인지상태 용어 사용 빈도 $(r=.30, p<.05)$ 과 관련이 있는 것으 로 나타났다. 따라서 추후 분석에서는 언어적 능력을 통제한 후 마음상태 용어 간 관련성을 살펴보았다.

\section{가상놀이에서 어머니와 유아가 사용한 마음상 태 용어 간 관계}

가상놀이에서 어머니와 유아가 사용하는 마음상태 용어 간 관 계를 살펴보기 위하여 언어적 능력을 통제한 후 편상관계수 를 산출하였다. 그 결과 어머니와 유아의 마음상태 용어 전체 의 사용 유형 간 상관은 $.34(p<.05)$ 로 나타나, 어머니가 다양 한 마음상태 용어를 사용할수록 유아도 다양한 마음상태 용어 를 사용하였다. 이를 하위범주별로 구분하여 살펴보면(Table
2), 첫째, 어머니가 사용한 욕구상태 용어 유형과 정서상태 용 어 유형 $(r=.43, p<.01)$, 그리고 정서상태 용어 유형과 인지상 태 용어 유형 $(r=.34, p<.05)$ 간 상관은 통계적으로 유의하였 다. 즉, 욕구상태 용어를 다양하게 사용한 어머니는 정서상태 용어도 다양하게 사용하였으며, 정서상태 용어를 다양하게 사 용한 어머니는 인지상태 용어를 다양하게 사용하였다. 하지만 욕구상태 용어를 다양하게 사용하는 것과 인지상태 용어를 다 양하게 사용하는 것에는 유의미한 관련성이 나타나지 않았다. 둘째, 유아가 사용하는 마음상태 용어의 유형 간 상관은 통계 적으로 유의하지 않았다. 셋째, 어머니와 유아가 사용하는 마 음상태 용어의 사용 유형 간 상관을 살펴본 결과, 어머니와 유 아의 욕구상태 용어와 정서상태 용어의 사용 유형 간에는 유 의한 상관이 나타나지 않았으나, 인지상태 용어의 사용 유형 간에는 유의한 정적 상관관계가 나타났다 $(r=.47, p<.01)$. 즉, 가상놀이에서 어머니가 인지상태 용어를 다양하게 사용할수 록 유아 역시 다양한 유형의 인지상태 용어를 사용하였다. 이 외에도, 어머니의 정서상태 용어와 유아의 인지상태 용어의 사용 유형 간 교차상관이 유의하게 나타나 $(r=.30, p<.05)$, 어 머니가 다양한 유형의 정서상태 용어를 사용할수록 유아는 다 
Table 2

Partial Correlations Between the Types of Mental State Terms Used by Mothers and Preschoolers During Pretend Play

\begin{tabular}{|c|c|c|c|c|c|c|}
\hline & 1 & 2 & 3 & 4 & 5 & 6 \\
\hline 1. Mothers' desire state term & - & & & & & \\
\hline 2. Mothers' emotion state term & $.43^{* *}$ & - & & & & \\
\hline 4. Preschoolers' desire state term & .23 & .20 & -.06 & - & & \\
\hline 5. Preschoolers' emotion state term & .11 & .21 & .02 & .03 & - & \\
\hline
\end{tabular}

Note. $N=50$.

${ }^{*} p<.05 .{ }^{* *} p<.01$.

Table 3

Partial Correlations Between the Frequencies of Mental State Terms Used by Mothers and Preschoolers During Pretend Play

\begin{tabular}{|c|c|c|c|c|c|c|}
\hline & 1 & 2 & 3 & 4 & 5 & 6 \\
\hline 1. Mothers' desire state term & - & & & & & \\
\hline 2. Mothers' emotion state term & $.26^{+}$ & - & & & & \\
\hline 4. Preschoolers' desire state term & $.48^{* * *}$ & .17 & -.04 & - & & \\
\hline 5. Preschoolers' emotion state term & -.10 & .24 & -.15 & -.10 & - & \\
\hline
\end{tabular}

Note. $N=50$.

${ }^{+} p<.10 .{ }^{*} p<.05 .{ }^{* * *} p<.001$.

양한 유형의 인지상태 용어를 사용하였다.

다음으로 가상놀이에서 어머니와 유아의 마음상태 용어 사용 빈도 간의 관계를 살펴본 결과, 어머니와 유아의 마음상 태 용어 사용 빈도 전체 간 상관은 통계적으로 유의하였다 $(r=$ $.41, p<.01)$. 이를 하위 범주별로 살펴보면(Table 3), 첫째, 어머 니가 사용한 욕구상태, 정서상태, 인지상태 용어 간 상관은 통 계적으로 유의하지 않았다. 둘째, 어머니의 경우와 마찬가지 로 유아가 사용한 마음상태 용어의 하위범주 간 상관은 유의 하지 않았다. 셋째, 어머니와 유아가 사용하는 마음상태 용어 의 사용 빈도 간 상관을 살펴본 결과, 어머니와 유아의 욕구상 태 용어 $(r=.48, p<.001)$ 와 인지상태 용어 $(r=.31, p<.05)$ 의 사 용 빈도 간에 통계적으로 유의한 상관이 있었다. 즉, 어머니가 욕구상태 용어를 많이 사용할수록 유아 역시 욕구상태 용어를 많이 사용하였고, 어머니가 인지상태 용어를 많이 사용할수록 유아 역시 인지상태 용어를 빈번하게 사용하였다. 이외 하위 범주 간 교차 상관은 유의하지 않았다.

\section{가상놀이에서 어머니와 유아가 사용한 마음상 태 용어와 가상적 내러티브에서 유아가 사용 한 마음상태 용어 간 관계}

가상놀이에서 어머니와 유아가 사용한 마음상태 용어와 가 상적 내러티브에서 유아가 사용한 마음상태 용어 간의 관계 를 살펴보기 위하여, 유아의 언어적 능력을 통제한 후 편상관 계수를 산출하였다. 먼저 사용 유형 간 상관과 관련하여, 가상 놀이와 가상적 내러티브 작성 시 유아가 사용한 마음상태 용 어 사용 유형 간 유의한 상관이 있었다 $(r=.37, p<.01)$. 하지만 가상놀이 시 어머니가 사용한 마음상태 용어 사용 유형은 가 상적 내러티브 작성 시 유아가 사용한 마음상태 용어 사용 유 형과 유의한 상관을 보이지 않았다. 하위범주 별 상관을 살펴 보면(Table 4), 유아가 가상놀이와 가상적 내러티브에서 사용 한 욕구상태 용어와 정서상태 용어 간, 그리고 가상놀이에서 사용한 욕구상태 용어와 가상적 내러티브에서 사용한 정서상 태 용어 간 상관이 통계적 유의성에 근접하기는 하였지만 $p<$ .10), 통계적으로 유의하지는 않았다. 
Table 4

Partial Correlations Between the Types of Mental State Terms Used During Pretend Play and in Hypothetical Narratives

\begin{tabular}{lccc}
\hline & & \multicolumn{2}{c}{ Hypothetical narrative } \\
\cline { 2 - 4 } \multicolumn{1}{c}{ Pretend play } & $\begin{array}{c}\text { Preschoolers' } \\
\text { desire state term }\end{array}$ & $\begin{array}{c}\text { Preschoolers' } \\
\text { emotion state term }\end{array}$ & $\begin{array}{c}\text { Preschoolers' } \\
\text { cognition state term }\end{array}$ \\
\hline Mothers' desire state term & .12 & -.12 & -.04 \\
Mothers' emotion state term & .21 & -.08 & .07 \\
Mothers' cognition state term & -.06 & .10 & $.24^{+}$ \\
Preschoolers' desire state term & $.28^{+}$ & $.27^{+}$ & .13 \\
Preschoolers' emotion state term & .03 & .09 & .08 \\
Preschoolers' cognition state term & .08 & .07 \\
\hline
\end{tabular}

Note. $N=50$.

${ }^{+} p<.10$.

Table 5

Partial Correlations Between the Frequencies of Mental State Terms Used During Pretend Play and in Hypothetical Narratives

\begin{tabular}{lccc}
\hline & & Hypothetical narrative \\
\cline { 2 - 4 } \multicolumn{1}{c}{ Pretend play } & $\begin{array}{c}\text { Preschoolers' } \\
\text { desire state term }\end{array}$ & $\begin{array}{c}\text { Preschoolers' } \\
\text { emotion state term }\end{array}$ & $\begin{array}{c}\text { Preschoolers' } \\
\text { cognition state term }\end{array}$ \\
\hline Mothers' desire state term & $.37^{* *}$ & -.01 & -.08 \\
Mothers' emotion state term & .03 & -.13 & -.01 \\
Mothers' cognition state term & -.09 & -.05 & .22 \\
Preschoolers' desire state term & $.31^{*}$ & .08 & -.08 \\
Preschoolers' emotion state term & -.08 & -.01 & .07 \\
Preschoolers' cognition state term & -.01 & .15 & \\
\hline
\end{tabular}

Note. $N=50$.

${ }^{*} p<.05 .{ }^{* *} p<.01$.

다음으로 사용 빈도와 관련하여, 가상놀이 상황에서 어머 니와 유아가 사용한 마음상태 용어 빈도와 가상적 내러티브 작성 시 유아가 사용한 마음상태 용어 빈도 간 상관은 유의하 지 않았다. 각 하위범주별로 살펴보면(Table 5), 첫째, 가상놀 이에서 어머니가 사용한 욕구상태 용어 빈도와 가상적 내러티 브에서 유아가 사용한 욕구상태 용어 빈도 간 유의한 상관관 계가 나타났으며 $(r=.37, p<.01)$, 가상놀이에서 어머니의 인 지상태 용어 빈도와 가상적 내러티브에서 유아의 인지상태 용 어 빈도 간에도 유의한 상관관계가 나타났다 $(r=.38, p<.01)$. 즉, 가상놀이에서 어머니가 욕구상태 용어와 인지상태 용어를 많이 사용할수록 가상적 내러티브에서 유아 역시 욕구상태 용 어와 인지상태 용어를 많이 사용하였다. 반면 가상놀이에서 어머니가 사용한 정서상태 용어와 가상적 내러티브에서 유아 가 사용한 정서상태 용어 간 상관은 유의하지 않았다. 둘째, 가 상놀이에서 유아가 사용한 욕구상태 용어 빈도와 가상적 내러 티브에서 유아가 사용한 욕구상태 용어 빈도 간에 유의한 상
관이 나타나 $(r=.31, p<.05)$, 가상놀이에서 욕구상태 용어를 많이 사용한 유아가 가상적 내러티브에서도 욕구상태 용어를 많이 사용하였다. 반면 가상놀이와 가상적 내러티브에서 유아 가 사용한 정서상태 용어와 인지상태 용어의 사용 빈도 간 상 관은 유의하지 않았다.

\section{논의 및 결론}

본 연구는 만 4세 유아와 어머니를 대상으로 가상놀이와 가상 적 내러티브의 두 상황에서 마음상태 용어의 사용 유형과 빈 도를 살펴보고, 어머니와 유아가 사용하는 마음상태 용어 간 관련성을 살펴보았다. 본 연구의 연구문제를 중심으로 주요 결과를 요약하고 논의하면 다음과 같다.

첫째, 가상놀이 상황에서 어머니와 유아가 사용한 마음상 태 용어를 사용 유형과 빈도로 구분하여 살펴본 결과, 어머니 
와 유아 모두 욕구상태 용어, 인지상태 용어, 정서상태 용어 순 으로 마음상태 용어를 다양하고 빈번하게 사용하였다. 이러 한 결과는 가상놀이에서 어머니(Osório et al., 2012)와 유아(J. Song \& Ohm, 2008)가 욕구상태 용어를 다른 범주의 마음상태 용어보다 더 많이 사용한 것으로 보고한 선행연구들과 일치 한다. 하지만 만 4 세 경 이후에는 욕구상태 용어의 사용은 감 소하고 인지상태 용어의 사용이 증가한다고 보고한 Bartsch와 Wellman (1995)의 연구결과나 36 70개월의 유아가 인지상태 용어를 가장 많이 사용한 것으로 보고한 Ji와 Jo (2010)의 연구 결과와는 일치하지 않는다. 이러한 결과는 마음상태 용어를 측정한 상황에서의 차이에 기인한 것으로 보이는데, Bartsch와 Wellman (1995)의 연구에서는 가상놀이가 아닌 부모-자녀 간 일상적인 대화에서, 그리고 Ji와 Jo (2010)는 그림책을 사용하 여 유아가 사용한 마음상태 용어를 분석하였기 때문에 가상놀 이에서 사용한 마음상태 용어를 분석한 본 연구의 결과와 차 이를 보였을 수 있다. 즉, 본 연구에서 사용한 가상놀이의 경우 원활한 놀이를 위해서는 어머니와 유아가 각자의 역할, 놀잇 감, 놀이 주제 등 놀이가 가지고 있는 가상적인 의미를 공유해 야 하기 때문에 자연스럽게 서로의 욕구나 바람을 더 많이 사 용하였기 때문인 것으로 보인다. 이러한 해석은 마음상태 용 어가 사용된 맥락에 따라 사용양상에 차이가 있음을 보고한 여러 선행연구들(Hoff-Ginberg, 1991; Howe et al., 2010; Laible, 2004)에 의해 뒷받침되며, 추후 연구에서는 다양한 상황을 포 함하여 마음상태 용어의 사용양상을 보다 심도 있게 분석할 필요가 있다.

가상놀이와 가상적 내러티브에서 유아가 사용한 마음상태 용어는 다소 차이를 보였다. 사용 빈도의 경우에는 두 상황 모 두에서 유아는 욕구상태, 인지상태, 정서상태 용어 순으로 마 음상태 용어를 사용하였지만, 사용 유형의 경우에는 가상놀이 에서는 욕구상태, 인지상태, 정서상태 용어 순으로, 가상적 내 러티브에서는 욕구상태, 정서상태, 인지상태 용어 순으로 마 음상태 용어를 다양하게 사용하여 다소 차이를 보였다. 이러 한 결과는 두 가지 측면에서 해석해 볼 수 있는데, 먼저 본 연 구에서 사용한 가상적 내러티브의 경우 각 이야기마다 갈등이 유발되는 상황이 제시되기 때문에 이로 인해 유아가 정서상태 용어를 더 다양하게 사용하였을 가능성이 있다. 또 다른 해석 으로는 이 시기 가상적 내러티브 작성이라는 상황 자체가 유 아로 하여금 가상적 상황에 등장하는 인물의 정서상태에 대해 더 표상하도록 할 가능성을 생각해 볼 수 있다. 일례로 본 연구 에서처럼 갈등상황을 유발하는 가상적 상황은 아니지만 유아 에게 일반적인 가상적 내러티브를 작성하게 하고 이를 분석한
Lee와 Lee (2006)의 연구에서도 3, 4, 5, 6세의 모든 연령 집단 에서 유아가 정서상태 용어를 인지상태 용어보다 더 많이 사 용하는 것으로 보고하고 있어 이러한 해석을 뒷받침한다. 마 음상태 용어를 측정하는 데 널리 사용되는 가상놀이 상황과 달리, 가상적 내러티브의 경우 유아의 마음상태 용어를 측정 하는 데 한정적으로만 사용되고 있어 추후 연구를 통해 가상 적 내러티브가 유아의 마음상태에 대한 표상 중 정서상태에 대한 표상을 더 촉진하는지 여부와 그 기제를 확인해 볼 필요 가 있다.

둘째, 유아의 언어적 능력은 가상놀이에서 어머니가 사용 하는 마음상태 용어 유형 전체와 인지상태 용어 사용 유형, 그 리고 가상적 내러티브에서 유아가 사용하는 욕구상태 용어 유형, 인지상태 용어 빈도와 관련이 있는 것으로 나타나 언어 적 능력이 높을수록 마음상태 용어를 좀 더 다양하고 빈번하 게 사용하는 것으로 나타났다. 유아의 언어적 능력과 마음상 태 용어 간 관련성을 살펴본 선행연구들(Bartsch \& Wellman, 1995; Cutting \& Dunn, 1999; J. Song \& Ohm, 2008)은 대부분 언어적 능력이 높을수록 유아가 마음상태 용어를 더 사용하는 것으로 보고하고 있어, 본 연구의 결과를 뒷받침한다. 또한 유 아의 어휘 수준을 높은 집단과 낮은 집단으로 구분하여, 어휘 력 수준이 높은 집단에 속한 유아들이 마음상태 용어를 유의 하게 더 많이 사용한 것으로 보고한 Lee와 Lee (2006)의 연구도 본 연구의 결과를 뒷받침한다. 선행연구와 본 연구의 결과는 마음상태 용어에 대한 언어적 이해가 이루어져야 주어진 상황 에서 마음상태 용어를 적절하게 사용하게 되는 것으로 해석해 볼 수 있지만, 본 연구의 경우 유아의 언어적 능력이 어머니와 유아가 사용한 마음상태의 모든 하위변인과 관련성을 가지고 있지는 않기 때문에 이러한 해석은 추후 연구를 통해 더 탐색 될 필요가 있다.

셋째, 가상놀이에서 어머니와 유아가 사용하는 마음상태 용어의 사용 유형 간, 그리고 사용 빈도 간 관계를 살펴본 결 과, 어머니가 마음상태 용어를 다양한 표현으로 사용하였을 경우 유아도 마음상태 용어를 다양하게 사용하였으며, 어머니 가 마음상태 용어를 더 많이 사용할수록 유아도 마음상태 용 어를 더 빈번하게 사용하였다. 선행연구들에서는 어머니와 유 아의 마음상태 용어 사용을 다양한 상호작용 상황을 통해서 연구하고 있지만, 모든 상황에서 어머니와 유아 간 마음상태 용어 사용 간 관련성은 일관적으로 보고되고 있다. 즉, 본 연 구의 결과는 가상놀이 상황을 사용한 연구(Osório et al., 2012) 뿐 아니라 그림책읽기 상황(Ji \& Jo, 2010), 일반적 상호작용 상 황(Jenkins et al., 2003), 혹은 과거회상 대화(Rudek \& Haden, 
2005)를 사용해 어머니와 유아 간 마음상태 용어의 관련성을 살펴본 선행연구들과 일치한다. 이는 유아가 일상적으로 시간 을 보내는 환경에서 자주 노출된 언어를 학습하여 사용한다는 Huttenlocher, Haight, Bryk, Seltzer와 Lyons (1991)의 주장과도 일맥상통한다. 비록 횡단적 연구설계를 사용한 본 연구의 특 성상 어머니의 마음상태 용어의 사용이 유아의 마음상태 용어 의 사용을 촉진하였다고 결론내릴 수는 없지만, 종단적 연구 설계를 사용한 Taumoepeau과 Ruffman $(2006,2008)$ 의 연구에 서는 초기 어머니의 마음상태 용어의 사용이 이후 유아의 마 음상태 용어를 예측하는 것으로 보고하고 있어 그 가능성을 제안하고 있다.

가상놀이에서 어머니와 유아가 사용한 마음상태 용어 간 관련성을 욕구상태, 정서상태, 인지상태의 하위범주별로 구분 하여 살펴본 결과, 어머니가 인지상태 용어를 다양한 표현으 로 사용하였을 경우 유아도 인지상태 용어를 다양하게 사용하 였으며, 어머니가 욕구상태 용어와 인지상태 용어를 더 많이 사용하였을수록, 유아도 같은 범주의 마음상태 용어를 더 빈 번하게 사용하였다. 먼저 인지상태 용어 사용의 경우 본 연구 의 결과는 어머니와 형제자매들이 인지상태 용어를 더 많이 사용할수록 유아가 인지상태 용어를 더 많이 사용하는 것으로 보고한 Jenkins 등(2003)의 연구와 일치한다. 즉 이 시기 가정 에서 인지상태 용어에 더 노출될수록, 유아는 다양한 인지상 태 용어들을 학습하게 되고 더 빈번하게 사용하게 된다는 것 이다. 이러한 결과는 인지상태 용어가 만 4세 경에 활발하게 학습되기 시작되어 그 사용이 증가한다는 점을 고려해 볼 때, 가상놀이 상황에서 어머니가 사용하는 인지상태 용어에 유아 가 더 주의 깊게 반응하였기 때문일 수 있다. 즉, 실제 어머니 와 유아가 가상놀이 시 더 많이 사용한 용어는 욕구상태 용어 이지만 놀이를 통해 유아가 더 많이 학습하고 있는 것은 인지 상태 용어일 가능성이 있다. 다음으로 어머니와 유아 간 사용 빈도 간 관련성만 나타난 욕구상태 용어의 경우, 선행연구들 또한 일관적인 결과를 보고하고 있지 않은데, 어머니와 유아 가 사용한 욕구상태 용어 간 관련성을 보고한 연구들(Osório et al., 2012; Symons et al., 2006)도 나타나고 있지만, 사용 유형 (Ji \& Jo, 2010)과 사용 빈도(Jenkins et al., 2003; Ji \& Jo, 2010) 모두에서 관련성을 찾지 못한 연구들도 동시에 나타나고 있 다. 욕구상태 용어의 경우 자녀가 어릴수록 더 큰 영향을 발휘 한다고 보고한 Taumoepeau와 Ruffman (2008)의 주장에 근거 하여 볼 때, 추후 연구에서는 마음상태 용어의 발달이 급격하 게 진행되는 유아기를 대상으로 각 연령별 어머니와 유아가 사용하는 마음상태 용어의 관련성에 차이가 있는지 살펴보는
것도 의미 있을 것이다.

한편, 정서상태 용어의 경우 어머니와 유아 간 관련성이 나 타나지 않았는데, Jenkins 등(2003)의 연구에서도 본 연구의 대 상보다 연령이 어린 경우에만 정서상태 용어 간 상관을 보고 하고 있어 본 연구의 결과와 일맥상통한다고 할 수 있다. 하지 만 Ji와 Jo (2010)는 어머니와 유아 간 정서상태 용어 사용 유형 간의 관련성을 보고하고 있어, 본 연구의 결과와는 상반된다. 이는 본 연구에서 가상놀이 시 정서상태 용어가 욕구상태 용 어나 인지상태 용어보다 상대적으로 적게 사용되었기 때문인 것으로 조심스럽게 해석해 볼 수 있다. 자신과 타인의 정서상 태를 이해하고 표현하는 능력은 유아기 원활한 사회적 관계를 형성하는 데 중요한 요인이므로(Denham et al., 2003; Miller et al., 2006), 이 시기 정서상태 용어가 더 많이 사용되고 학습될 수 있는 상호작용 상황을 밝혀내는 것도 의미 있는 연구가 될 것이다.

마지막으로, 가상놀이에서 어머니와 유아가 사용한 마음상 태 용어와 가상적 내러티브에서 유아가 사용한 마음상태 용어 가 관계가 있는지 살펴본 결과, 가상놀이에서 다양한 마음상 태 용어를 사용한 유아는 가상적 내러티브에서도 다양한 마음 상태 용어를 사용하였지만, 사용 빈도 간 관련성은 유의하지 않았다. 이를 하위범주별로 구분하여 살펴보면, 가상놀이에서 어머니와 유아가 사용한 욕구상태 용어는 가상적 내러티브에 서 유아가 사용한 욕구상태 용어와 유의한 관련이 있었다. 또 한 인지상태 용어의 경우에는 가상놀이에서 어머니가 사용한 인지상태 용어만이 가상적 내러티브에서 유아가 사용한 인지 상태 용어와 관련이 있었다. 비록 가상적 내러티브에서 유아 가 사용한 마음상태 용어를 다른 상황에서 사용한 마음상태 용어와 비교한 연구가 없고, 어머니, 형제자매, 친구와의 상호 작용 상황에서 유아의 마음상태 용어 사용을 살펴본 Brown 등 (1996)의 연구에서도 상황에 따른 마음상태 용어의 차이만을 살펴보았기 때문에 본 연구의 결과를 직접적으로 비교하여 해 석하기는 힘들다. 다만 가상놀이에서 어머니가 사용한 마음상 태 용어가 가상놀이와 가상적 내러티브에서 유아가 사용한 마 음상태 용어와 유사한 경향의 관련성을 보이는 것으로 나타난 본 연구의 결과를 통해 어머니가 가상놀이에서 사용한 마음상 태 용어가 유아가 독립적으로 사용한 마음상태 용어로 이어짐 을 확인할 수 있었다. 추후 연구에서는 종단적인 연구설계를 통해 마음상태 용어가 내면화되는 과정과 관련변인을 탐색할 필요가 있다.

본 연구의 제한점과 이에 기초한 후속 연구를 위한 제언은 다음과 같다. 첫째, 본 연구는 가상놀이와 가상적 내러티브를 
통해 어머니와 유아의 마음상태 용어의 사용양상 및 관련성을 분석하였는데, 추후 연구에서는 일상적 환경에서 자연적으로 나타나는 마음상태 용어를 포함하여 다양한 상황에서 나타나 는 마음상태 용어를 측정할 필요가 있다. 둘째, 본 연구는 만 4 세 유아만을 대상으로 횡단적 연구설계를 통해 어머니와 유 아의 마음상태 용어를 측정하였기 때문에 발달적 차이와 변 인 간 인과관계를 규정할 수 없다는 제한점이 있다. 후속연구 에서는 다양한 연령집단을 포함하여 마음상태 용어에서의 발 달적 차이를 살펴봄과 더불어 종단적인 연구 설계를 통해 어 머니가 사용하는 마음상태 용어가 유아의 마음상태 용어에 영 향을 미쳐 개인적인 특성으로 내면화되는 과정을 살펴볼 필요 가 있다. 일례로, 유아가 어머니와의 상호작용 시 사용한 마음 상태 용어가 이후 또래집단 내에서 사용하는 마음상태 용어에 영향을 미치는지 등을 살펴보는 것도 흥미로울 것이다. 마지 막으로, 본 연구의 결과는 샘플 수의 제한으로 그 결과를 일반 화하기에 한계가 있다. 또한 연구대상자의 표집과 관련하여, 본 연구에서는 어린이집과 인터넷 육아 카페의 두 가지 경로 로 연구대상을 모집하였기 때문에 참여 경로 및 자발적인 참 여 의사 정도가 연구 결과에 영향을 미쳤을 가능성이 있다. 따 라서 추후 연구에서는 보다 대표성을 확보할 수 있는 모집 방 법을 사용하여 충분한 사례수를 확보하여 본 연구의 결과를 타당화할 필요가 있다.

이러한 제한점에도 불구하고, 본 연구는 유아기 마음상태 용어의 사용에 대한 연구가 많지 않은 국내 상황에서, 가상놀 이와 가상적 내러티브 두 상황에서 어머니와 유아의 마음상 태 용어의 사용과 관련성을 살펴보았다는 데 의의가 있다. 특 히 가상놀이에서 어머니가 사용한 마음상태 용어가 가상적 내 러티브에서 유아가 보이는 마음상태 용어와 관련이 있음을 밝 힘으로써, 이 시기 어머니와의 상호작용을 통해 유아가 마음 상태 용어를 학습하고 있음을 확인할 수 있었다. 즉, Vygotsky (1978)의 발판화와 Rogoff (1990)의 참여된 안내 개념에서 제 안하는 것처럼, 어머니와의 상호작용을 통해 유아가 마음상태 용어를 학습하고, 이를 내면화하는 과정에 대한 기초적 자료 를 제공하였다는 데 의의가 있다. 본 연구의 결과를 통해 유아 의 마음상태 용어의 발달을 위해서는 가정에서 어머니가 다양 한 상호작용 상황을 이용하여 유아의 마음상태 용어를 촉진할 필요가 있음을 알 수 있다. 또한 추후 연구에서는 유아가 어머 니와의 상호작용을 통해 학습하고 내면화 한 마음상태 용어를 또래와의 상호작용에서 어떻게 사용하는지, 그리고 마음상태 용어가 가지고 있는 언어적, 표상적 의미에 대한 이해를 바탕 으로 보다 폭넓은 마음상태에 대한 이해가 이루어지고 있는지
여부를 종단적인 연구설계를 통해 살펴볼 필요가 있다.

\section{Acknowledgements}

This work was supported by the National Research Foundation of Korea Grant funded by the Korean Government (NRF-2013S1A5A 8024925).

\section{Conflict of Interest}

No potential conflict of interest relevant to this article was reported.

\section{References}

Adrian, J. E., Clemente, R. A., Villanueva, L., \& Rieffe, C. (2005). Parent-child picture-book reading, mothers' mental state language and children's theory of mind. Journal of Child Language, 32(3), 673-686. doi:10.1017/ S0305000905006963

Bartsch, K., \& Wellman, H. M. (1995). Children talk about the mind. New York, NY: Oxford University Press. doi: 10.1002/1520-6807(199601)33:1<87::AIDPITS2310330105>3.0.CO;2-C

Bettmann, J. E., \& Lundahl, B. W. (2007). Tell me a story: A review of narrative assessments for preschoolers. Child and Adolescent Social Work Journal, 24(5), 455-475. doi:10.1007/s10560-007-0095-8

Bretherton, I., \& Beeghly, M. (1982). Talking about internal states: The acquisition of an explicit theory of mind. Developmental Psychology, 18(6), 906-921. doi:10.1037/0012-1649.18.6.906

Bretherton, I., Oppenheim, D., Buchsbaum, H., \& Emde, R. N. (1990). The MacArthur Story Stem Battery (MSSB). Unpublished Manual, University of Wisconsin-Madison, USA. doi: 10.13140/RG.2.1.2376.9442

Brown, J. R., Donelan-McCall, N., \& Dunn, J. (1996). Why talk about mental states? The significance of children's conversations with friends, siblings, and mothers. Child Development, 67(3), 836-849. doi:10.1111/j.14678624.1996.tb01767.x

Brown, J. R., \& Dunn, J. (1991). "You can cry, mum": The social and developmental implications of talk about internal states. British Journal of Developmental Psychology, 9(2), 237-256. doi:10.1111/j.2044-835X.1991.tb00874.x 
Carlson, S. M., Mandell, D. J., \& Williams, L. (2004). Executive function and theory of mind: Stability and prediction from ages 2 to 3. Developmental Psychology, 40(6), 1105-1122. doi:10.1037/0012-1649.40.6.1105

Comparini, L., Douglas, E. M., \& Perez, S. N. (2014). The development of social cognition: Preschoolers' use of mental state talk in peer conflicts. Early Education and Development, 25(7), 1083-1101. doi:10.1080/10409289.2 014.896770

Cutting, A, L., \& Dunn, J. (1999). Theory of mind, emotion understanding, language and family background: Individual differences and inter-relations. Child Development, 70(4), 853-865. doi:10.1111/1467-8624.00061

Denham, S. A., Blair, K. A., DeMulder, E., Levitas, J., Sawyer, K., Auerbach-Major, S., \& Queenan, P. (2003). Preschool emotional competence: Pathway to social competence? Child Development, 74(1), 238-256. doi:10.1111/1467-8624.00533

Dunn, J., Bretherton, I., \& Munn, P. (1987). Conversations about feeling states between mothers and their young children. Developmental Psychology, 23(1), 132-139. doi:10.1037/00121649.23.1.132

Dyer, J. R., Shatz, M., \& Wellman, H. M. (2000). Young children's storybooks as a source of mental state information. Cognitive Development, 15(1), 17-37. doi:10.1016/S08852014(00)00017-4

Flavell, J. H. (2000). Development of children's knowledge about the mental world. International Journal of Behavioral Development, 24(1), 15-23. doi:10.1080/016502500383421

Haight, W. L., \& Miller, P. J. (1993). Pretending at home: Early development in a sociocultural context. Albany, NY: State University of New York Press.

Hoff-Ginsberg, E. (1991). Mother-child conversation in different social classes and communicative settings. Child Development, 62(4), 782-796. doi:10.1111/j.1467-8624.1991.tb01569.x

Howe, N., Rinaldi, C. M., \& Recchia, H. E. (2010). Patterns in mother-child internal state discourse across four contexts. Merrill-Palmer Quarterly, 56(1), 1-20. doi:10.1353/ mpq.0.0042

Hughes, C., \& Dunn, J. (1997). "Pretend you didn't know": Preschooler's talk about mental states in pretend play. Cognitive Development, 12(4), 477-497. doi:10.1016/S08852014(97)90019-8

Hughes, C., \& Dunn, J. (1998). Understanding mind and emotion: Longitudinal associations with mental-state talk between young friends. Developmental Psychology, 34(5), 1026-1037. doi:10.1037/0012-1649.34.5.1026

Hughes, C., Marks, A., \& Ensor, R. (2009). A longitudinal study of conflict and inner state talk in children's conversations with mothers and younger siblings. Social Development, 19(4), 822837. doi:10.1111/j.1467-9507.2009.00561.x
Hughes, C., Lecce, S., \& Wilson, C. (2007). "Do you know what I want?" Preschoolers' talk about desires, thoughts and feelings in their conversations with sibs and friends. Cognition and Emotion, 21(2), 330-350. doi:10.1080/02699930600551691

Huttenlocher, J., Haight, W., Bryk, A., Seltzer, M., \& Lyons, T. (1991). Early vocabulary growth: Relation to language input and gender. Developmental Psychology, 27(2), 236248. doi:10.1037/0012-1649.27.2.236

Jenkins, J. M., \& Astington, J. W. (2000). Theory of mind and social behavior: Causal models tested in a longitudinal study. Merrill-Palmer Quarterly, 46(2), 203-220. Retrieved from http://www.jstor.org/stable/23093714

Jenkins, J. M., Turrell, S. L., Kogushi, Y., Lollis, S., \& Ross, H. S. (2003). A longitudinal investigation of the dynamics of mental state talk in families. Child Development, 74(3), 905-920. doi:10.1111/1467-8624.00575

Ji, E. J., \& Jo, H. S. (2010). The relationship between mothers' mental state terms and children's. The Journal of Korea Open Association for Early Childhood Education, 15(1), 235261.

Kim, H. J. (2014). Mental-state talks of mothers with 2-year-olds in pretense/role-play and book reading contexts. Journal of Korean Child Care and Education, 10(2), 133-151. doi: 10.14698/jkcce.2014.10.2.133

Kim, Y. S., \& Lee, J. H. (2003). Symbolic levels of early pretense and representational thinking. Korean Journal of Child Studies, 24(5), 1-14. Retrieved from http://childstudies.org/ journal/view.php?number=2599

Kuebli, J., Butler, S., \& Fivush, R. (1995). Mother-child talk about past emotions: Relations of maternal language and child gender over time. Cognition \& Emotion, 9(2-3), 265-283. doi:10.1080/02699939508409011

Laible, D. (2004). Mother-child discourse in two contexts: Links with child temperament, attachment security, and socioemotional competence. Developmental Psychology, 40(6), 979-992. doi:10.1037/0012-1649.40.6.979

Leaper, C., Anderson, K. J., \& Sanders, P. (1998). Moderators of gender effects on parents' talk to their children: A meta-analysis. Developmental Psychology, 34(1), 3-27. doi:10.1037/0012-1649.34.1.3

Lee, Y. J., \& Lee, J. H. (2006). Young children's use of mental state terms in narratives according to the Levels of narrative development, theory of mind, and vocabulary. The Journal of Korea Open Association for Early Childhood Education, 11(1), 153-178.

Lee, Y. J., Lee, J. S., \& Shin, E. S. (2004). Differences in young children`s levels of language functions of pretend play, vocabulary, and mental state term expressions for young children according to the theory of mind. Journal of Early 
Childhood Education, 24(4), 141-160.

Lee, Y. J., \& Oh, J. H. (2007). The effects of picturebook reading and emotional state discourse on young children's development of fictional narratives and theory of mind. Journal of Early Childhood Education, 27(3), 245-271.

Miller, A. L., Fine, S. E., Gouley, K. K., Seifer, R., Dickstein, S., \& Shields, A. (2006). Showing and telling about emotions: Interrelations between facets of emotional competence and associations with classroom adjustment in Head Start preschoolers. Cognition and Emotion, 20(8), 1170-1192. doi:10.1080/02699930500405691

Moore, C., Furrow, D., Chiasson, L., \& Patriquin, M. (1994). Developmental relationships between production and comprehension of mental terms. First Language, 14(40), 1-17. doi: $10.1177 / 014272379401404001$

Nelson, K. (2005). Language pathways into the community of minds. In J. W. Astington \& J. A. Baird (Eds.), Why language matters for theory of mind (pp. 26-49). New York, NY: Oxford University Press.

Nielsen, M., \& Dissanayake, C. (2000). An investigation of pretend play, mental state terms and false belief understanding: In search of a metarepresentational link. British Journal of Developmental Psychology, 18(4), 609-624. doi:10.1348/026151000165887

Ontai, L. L., \& Thompson, R. A. (2008). Attachment, parentchild discourse and theory-of-mind development. Social Development, 17(1), 47-60. doi:10.1111/j.14679507.2007.00414.x

Osório, A., Meins, E., Martins, C., Martins, C. E., \& Soares, I. (2012). Child and mother mental-state talk in shared pretense as predictors of children's social symbolic play abilities at age 3. Infant Behavior \& Development, 35(4), 719-726. doi:10.1016/j.infbeh.2012.07.012

Park, H. W., Kwak, K. J., \& Park, K. B. (1996). Korean-Wechsler Primary Preschool Scale of Intelligence: K-WPPSI. Seoul: Special Education.

Park, K. J., \& Kwon, M. G. (2011). Young children's optimism in the relationship with mental state terms and story structure development. Science Review, 37, 131-146.

Robinson, J. L. (2007). Story stem narratives with young children: Moving to clinical research and practice. Attachment \& Human Development, 9(3), 179-185. doi:10.1080/14616730701453697

Rogoff, B. (1990). Apprenticeship in thinking. New York, NY: Oxford University Press.

Rosnay, M. D., \& Hughes, C. (2006). Conversation and theory of mind: Do children talk their way to socio-cognitive understanding? British Journal of Developmental Psychology, 24(1), 7-37. doi:10.1348/026151005X82901

Rudek, D. J., \& Haden, C. A. (2005). Mothers' and preschoolers' mental state language during reminiscing over time. Merrill-Palmer Quarterly, 51(4), 523-549. Retrieved from http://www.jstor.org/stable/23096100

Ruffman, T., Slade, L., \& Crowe, E. (2002). The relation between children's and mother's mental state language and theoryof-mind understanding. Child Development, 73(3), 734751. doi:10.1111/1467-8624.00435

Shatz, M., Wellman, H. M., \& Silber, S. (1983). The acquisition of mental verbs: A systematic investigation of the first reference to mental state. Cognition, 14(3), 301-321. doi:10.1016/0010-0277(83)90008-2

Song, Y. J. (2009). Children's mind-related-expressions in story making and their relations to theory of mind. The Journal of Korea Open Association for Early Childhood Education, $14(3), 425-446$.

Song, J., \& Ohm, J. A. (2008). The relationship between the use of mental state terms and theory of mind in the sociodramatic play of 4 year-old children. Journal of Early Childhood Education, 28(2), 69-94.

Symons, D. K. (2004). Mental state discourse, theory of mind, and the internalization of self-other understanding. Developmental Review, 24(2), 159-188. doi:10.1016/ j.dr.2004.03.001

Symons, D. K., Fossum, K. L. M., \& Collins, T. B. (2006). A longitudinal study of belief and desire state discourse during mother-child play and later false belief understanding. Social Development, 15(4), 676-692. doi:10.1111/j.14679507.2006.00364.x

Symons, D. K., Peterson, C. C., Slaughter, V., Roche, J., \& Doyle, E. (2005) Theory of mind and mental state discourse during book reading and story-telling tasks. British Journal of Developmental Psychology, 23(1), 81-102. doi:10.1348/026151004X21080

Tamis-LeMonda, C. S., \& Bornstein, M. H. (1990). Language, play, and attention at one year. Infant Behavior and Development, 13(1), 85-98. doi: 10.1016/0163-6383(90)90007-U

Taumoepeau, M., \& Ruffman, T. (2006). Mother and infant talk about mental states relates to desire language and emotion understanding. Child Development, 77(2), 465-481. doi:10.1111/j.1467-8624.2006.00882.x

Taumoepeau, M., \& Ruffman, T. (2008). Stepping stones to others' minds: Maternal talk relates to child mental state language and emotion understanding at 15, 24, and 33 months. Child Development, 79(2), 284-302. doi:10.1111/ j.1467-8624.2007.01126.x

Thompson, R. A. (2006). The development of the person: Social understanding, relationships, conscience, self. In W. Damon (Series Ed.), Handbook of Child Psychology: Vol. 3. Social, emotional, and personality development (6th ed., pp. 2498). Hoboken, NJ: Wiley. doi:10.1002/9780470147658. 
chpsy0302

Vygotsky, L. S. (1978). Mind in society: The development of higher psychological processes. Cambridge, MA: Harvard University Press.

Wellman, H. M., Cross, D., \& Watson, J. (2001). Meta-analysis of theory-of-mind development: The truth about false belief. Child Development, 72(3), 655-684. doi:10.1111/14678624.00304

Wellman, H. M., \& Woolley, J. D. (1990). From simple desires to ordinary beliefs: The early development of everyday psychology. Cognition, 35(3), 245-275. doi:10.1016/00100277(90)90024-E

Ziv, M., Smadja, M. L., \& Aram, D. (2013). Mothers' mentalstate discourse with preschoolers during storybook reading and wordless storybook telling. Early Childhood Research Quarterly, 28(1), 177-186. doi:10.1016/j.ecresq.2012.05.005

\section{ORCID}

Nana Shin http://orcid.org/0000-0002-7869-6875

Soyoung Kim http://orcid.org/0000-0003-0276-5237

Received February 29, 2016

Revision received April 11, 2016

Accepted April 22, 2016 